\title{
Café Au Lait Spots as a Marker of Neuropaediatric Diseases
}

\author{
Francisco Carratalá-Marco ${ }^{1 *}$, Rosa María Ruiz-Miralles ${ }^{2}$, Patricia Andreo-Lillo ${ }^{1}$, Julia Dolores Miralles-Botella ${ }^{3}$, \\ Lorena Pastor-Ferrándiz ${ }^{1}$ and Mercedes Juste-Ruiz ${ }^{2}$
}

${ }^{1}$ Neuropaediatric Unit, University Hospital of San Juan de Alicante, Spain

${ }^{2}$ Paediatric Department, University Hospital of San Juan de Alicante, Spain

${ }^{3}$ Dermatology Department, University Hospital of San Juan de Alicante, Spain

Submission: March 22, 2017; Published: May 10, 2017

*Corresponding author: Francisco Carratalá-Marco, Neuropaediatric Unit, University Hospital of San Juan de Alicante, Spain, Tel: +34 606310944

; Email: fcarratalamarco@gmail.com

\begin{abstract}
Introduction: The Café au lait spots (CALS) are shown in the normal population without pathological significance, although they could also be criteria for some neurologic syndromes. Unspecific association with general neurologic illnesses has been less frequently described. We want to know in which measure, the presence of isolated CALS represents a risk factor for neurological disease.

Patients and methods: We set up an observational transversal study of cases, patients admitted for neuropaediatric reasons (NPP; $n=49$ ) excluding all the patients suffering from neurologic illnesses associated to CALS, and controls, a hospital simultaneously admitted pediatric population for non-neurologic causes (CP; $n=101$ ) since October 2012 to January 2013. The data were collected from the clinical reports at admission, and then analyzed by SPSS 22.0 statistical package, and the Stat Calc module of EpiInfo 7.0, following the ethics current rules of the institution for observational studies.

Results: Twelve out of 49 NPP (24.4\%) showed at least one CALS, while only 10 out of 101 PC (9.9\%) (OR= 4.38; IC=1.03-19.74) did it, being the probability of showing CALS at least 4 times significantly higher in the NPP group than in the CP group. The epileptic patients $(X 2=14.19 ; p=0.0002)$ and those admitted for encephalopathy studies $(X 2=45.7 ; p=0.000000)$ showed a significantly higher prevalence of de CALS.

Conclusion: The prevalence of CALS was significantly higher among the patients admitted because of neurologic problems excluding syndromes or illnesses associated to them.

Keywords: Café au lait spots; Epilepsy; Neuropaediatrics; Intractable headaches; Encephalopathy

Abbreviations: CALS: Café Au Lait Spots; NPP: Neuropaediatric Patients Group; CP: Control Patients Group; OR: Odds Ratio; CNS: Central Nervous System
\end{abstract}

\section{Introduction}

The relationship between the development of CNS disorders and the presence of hyper- and hypo pigmentary lesions on the skin of the pediatric patient has been known since the earliest descriptions of syndromes involving the CNS [1,2]. Its importance lies not only in its clinical relevance, but also in the fact that the neurophysiological bases of this relationship remain the key to the understanding of neuro developmental pathological processes, especially those that manifest in the pediatric age [3]. Within the cutaneous macules that appear as dyschromia, the hyper pigmented ones, especially the so-called café au lait spots (CALS) are the most recognizable by their tone and shape and their less variability with respect to other types of dyschromia. This has allowed them to be easily associated with a series of clinical syndromes for which the diagnosis becomes a major criterion, such as Neurofibromatosis type 1 $[4,5]$. The high prevalence of this type of cutaneous pigmentary abnormalities that appear among patients with mutations in mTOR genes, suggests that the pathophysiological mechanism that mediates their appearance uses the same systems by which the proliferation of other cell lines leads to the formation of neoplastic lesions [4-7], especially in the early stages of life in 


\section{Open Access Journal of Neurology \& Neurosurgery}

which the cutaneous clinic expression is minimal [5]. It is also known that the presence of CALS does not always indicate pathology or risk of it. It has been described that approximately $75 \%$ of the patients attending to dermatological clinics present these spots in isolation and without association with pathology, which represented $0.17 \%$ of a population of care of all ages [8]. Studies in the neonatal period show that skin lesions are not uncommon, although the presence of CALS does not exceed $1.3 \%$ of all cutaneous anomalies in this period [9]. It has been documented its highest prevalence among patients with less specific neurological alterations such as epilepsy, among whom it was found that $28 \%$ of the patients had CALS, being their most common cutaneous finding [2]. Thus, the main objective of this study is to verify if there is a higher prevalence of CALS among patients admitted with neuropediatric pathology (NPP), compared to a group of control patients (CP) exempt from this pathology, admitted simultaneously in the same paediatric wards.

\section{Patients and Methods}

A cross-sectional observational study of cases (NPP; $n=$ 49) and controls ( $\mathrm{CP} ; \mathrm{n}=101)$ was carried out among patients admitted to a university hospital with a paediatric reference area (0-15 years) of 33731 children. The study was conducted during the 11-month period between October 2012 and August 2013. Patients who had been admitted as cases had to have a neurological entry reason different from known syndromes that associated CALS. The following pathological groups were recorded: Studies for suspected or non-evolutionary encephalopathies, epilepsy, follow-up for atypical headaches, gait disorders and complicated febrile seizures (Table 1). The presence of CALS was always computed as a demonstration of a hyperchromic lesion, at least one $\mathrm{cm}$ larger in diameter, similar to coffee with milk (Figure 1). The number of CALSs that appear in each group was recorded, as well as its aspect and location. The control group was formed by taking the skin stigma examination data from two children admitted at the same time as the case, and who do not present neurological disease nor record of previous admission or follow-up for these type of pathology. The cause of

Table 1: Description of study population and pathologies analyzed.

\begin{tabular}{|c|c|c|c|}
\hline & Cases (PPN) & Control (CP) & \\
\hline $\mathrm{N}=$ & 49 & 101 & $\mathrm{~ns}$ \\
\hline $\begin{array}{c}\text { Gender } \\
\text { distribution } \\
\text { (boys/girls) }\end{array}$ & $24 / 25$ & $51 / 50$ & $\mathrm{p}=0.0001$ \\
\hline $\begin{array}{c}\text { Mean (Media } \\
\pm \text { SD) }\end{array}$ & $5.9 \pm 4.3$ & $3.4 \pm 3.2$ & $\begin{array}{c}\text { "T" }=4.139 ; \\
\mathrm{p}\end{array}$ \\
\hline $\begin{array}{c}\text { Admission } \\
\text { diagnosis }\end{array}$ & 12 & - & \\
\hline Epilepsy & 14 & - & \\
\hline $\begin{array}{c}\text { Encephalopathy } \\
\text { studies }\end{array}$ & & & \\
\hline
\end{tabular}

\begin{tabular}{|c|c|c|c|}
\hline Gate impairment & 3 & - & \\
\hline Headache & 4 & - & \\
\hline $\begin{array}{c}\text { Complex febrile } \\
\text { convulsions }\end{array}$ & 9 & - & \\
\hline Temperature & - & 9 & \\
\hline $\begin{array}{c}\text { Respiratory } \\
\text { distress }\end{array}$ & - & 23 & \\
\hline Vomiting & - & 24 & \\
\hline Pneumonia & - & 14 & \\
\hline $\begin{array}{c}\text { Other non- } \\
\text { neurologic }\end{array}$ & - & 28 & \\
\hline
\end{tabular}

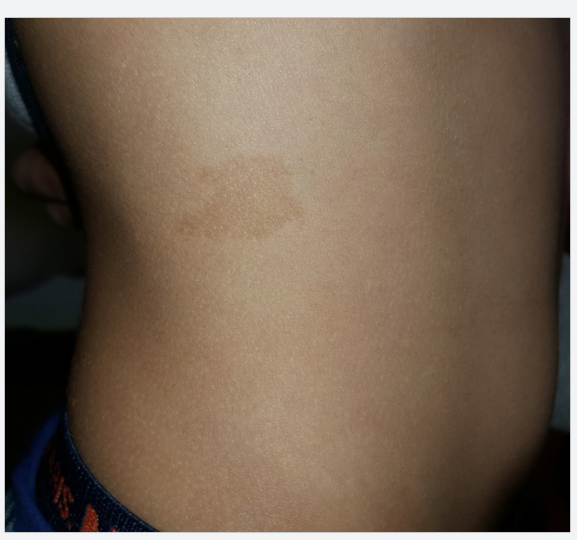

Figure 1: Isolated Café au lait spot in a 7 year old boy followed because of a benign lobar epilepsy.

admissions for these patients were: pneumonia, uncontrollable vomiting, respiratory distress, fever, and other reasons that included follow-up studies in non-neurological pathologies (Table 1). All the patients studied belonged to the hospital's health department. The data were collected and tabulated following the current regulations for observational studies. After data anonymous registration, these were analyzed with the statistical program SPSS.22 with the frequency modules and comparison of unpaired means, and with the Statcalc module of Epi Info 7 for the calculation of the Odds ratio (OR).

\section{Results}

Twelve (24\%) out of the 49 NPPs, presented at least one CALS, whereas only $10(9,9 \%)$ out of 101 CPs did it, showing a probability of having CALS at least four times significantly higher in the NPP group than in the CP group (OR = 4.38; $\mathrm{CI}$ $=1.03-19.74$ ) (Table 2). Twelve (24\%) out of the 49 NPPs suffered from epilepsy, six of which $(50 \%)$ presented CALS, which compared with the lowest percentage $(9.9 \%)$ of the CP presented statistically significant differences $\mathrm{OR}=9.1(2.08$ 40.95). Same results were observed for patients admitted for encephalopathy study, gait disorders, headache who required admission for their treatment and complicated febrile seizures (Table 2). The distribution or shape of the spots did not show significant differences between the PPN and PC, as well as between the different PPN categories. 
Table 2: Global association and by neuropediatric pathologies of the patients who presented coffee-to-milk stains (CALS) versus the group of control patients (CP).

\begin{tabular}{|c|c|c|c|}
\hline Cases (PPN) & $12(24.5 \%)$ & $37(75.5 \%)$ & $\begin{array}{c}\text { OR=4.38(1.03- } \\
19.74)\end{array}$ \\
\hline Epilepsy & $6(50 \%)$ & $6(5.9 \%)$ & $\begin{array}{c}\text { OR=9.1(2.08- } \\
40.95)\end{array}$ \\
\hline $\begin{array}{c}\text { Encephalopathy } \\
\text { studies }\end{array}$ & $12(85.7 \%)$ & $2(4,1 \%)$ & $\begin{array}{c}\text { OR=54.6(9.37- } \\
417)\end{array}$ \\
\hline $\begin{array}{c}\text { Gate } \\
\text { impairment }\end{array}$ & $2(66.6 \%)$ & $1(33.3 \%)$ & $\begin{array}{c}\text { OR=18.2(1.13- } \\
562)\end{array}$ \\
\hline $\begin{array}{c}\text { Headache } \\
\text { Complex febrile } \\
\text { convulsions }\end{array}$ & $5(55.5 \%)$ & $4(44.4 \%)$ & $\begin{array}{c}\text { OR=11.38(2.16- } \\
63.1)\end{array}$ \\
\hline $\begin{array}{c}\text { Controls (CP) } \\
\text { (C) }\end{array}$ & $10(9.9 \%)$ & $91(90.1 \%)$ & $949)$ \\
\hline
\end{tabular}

\section{Discussion}

Contrary to our results, no published studies have been found that globally relate the presence of CALS with an increased risk of suffering from neuropediatric and neurodevelopment diseases. There are studies that relate this type of dyschromia to specific pathologies such as epilepsy, which also excluded the syndromes that associate CALSs as a constitutive characteristic of them [8]. Our values are comparable to those of other larger series (2964 patients) presented by Karabiber et al. [10] in which the risk is similar (OR $=9.2 ; \mathrm{CI}=6.24-13.59$ ) although the age range differs, since in our population was between $0-15$ years and those of the cited author was 2-17 years old [10]. To the knowledge of the authors, there are no studies in which the neurological conditions studied, such as encephalopathies, gait impairments, headaches and complicated febrile convulsions, occur more frequently in patients with CALS. However, the small number of patients enrolled in each of these pathology subgroups in our study, weakened the clinical value of our results. As has been pointed out, the list of diseases that are going to give CALS as cutaneous manifestations is very broad, and continues to grow with the new findings of genetics in which new mutations simultaneously associate cutaneous and CNS manifestations [4,11-14].

It also can be pointed out that outside of classic neurocutaneous syndromes and related pathologies, little is known about the actual pathological significance of these cutaneous stigmas when presented in isolation. Nevertheless, our results indicate that scrutinizing the patient in search of these stigmas may be fundamental for an adequate diagnostic orientation of these pathologic conditions. Thus, the pediatrician of primary care, who despite the time of consultation provided by health administrations, takes his time for cutaneous revision and detects these CALSin a patient who consulted for dizziness, sleep disorders, episodes of disorientation or abnormal movements, has almost 10 times more chances to make a correct suspicion of epileptic seizures that if he ignores its existence, and therefore a clear indication of the patient's referral to a neuropaediatric unit. From the point of view of clinical practice, and from what has been exposed so far, the follow-up of this type of patients is highly recommended, not only for early detection of some classic neurocutaneous syndromes, but also for the possibility of nonspecific abnormalities of the CNS that may lead to pathology such as epilepsy $[10,15]$.

\section{References}

1. Whitehouse D (1966) Diagnostic value of the café-au-lait spot in children. Arch Dis Child 41(217): 316-319.

2. Abeliovich D, Gelman-kohan Z, Silverstein S, Lerer I, Chemke J, et al. (1995) Jmedgene00279-0067, pp. 985-986.

3. Nakamura H, Martinez S (2016) Preface to the special issue, Embryonic and adult neurogenesis in vertebrate. Dev Growth Differ 58(5): 425426.

4. Ferner RE, Huson SM, Thomas N, Moss C, Willshaw H, et al. (2007) Guidelines for the diagnosis and management of individuals with neurofibromatosis 1. J Med Genet 44(2): 81-88.

5. Duat Rodríguez A, Martos Moreno G, Martín Santo-Domingo Y, Hernández Martín A, Espejo-Saavedra Roca JM, et al. (2015) Características fenotípicas y genéticas en la neurofibromatosis tipo 1 en edad pediátrica. An Pediatr 83(3): 173-182.

6. Rosner M, Hanneder M, Siegel N, Valli A, Fuchs C, et al. (2008) The mTOR pathway and its role in human genetic diseases. Mutat Res 659(3): 284-292.

7. Brems H, Beert E, de Ravel T, Legius E (2009) Mechanisms in the pathogenesis of malignant tumours in neurofibromatosis type 1 . Lancet Oncol 10(5): 508-515.

8. Pérez Hernández J, Frías Ancona G, Vergara López A (2010) Prevalencia de las manchas café con leche en pacientes de consulta externa del servicio de Dermatología del Centro Médico Nacional 20 de Noviembre. Dermatologia Rev Mex 54(6): 315-320.

9. Haveri FTTS, Inamadar AC (2014) A Cross-Sectional Prospective Study of Cutaneous Lesions in Newborn. ISRN Dermatol 2014: 1-8.

10. Karabiber H, Sasmaz S, Turanli G YC (2002) Prevalence of hypopigmented maculae and café-au-lait spots in idiopathic epileptic and healthy children. J Child Neurol 17(1): 57-59.

11. Erdenen F, Gürel MS, Canöz MB, Günel Ș, Canöz B, et al. (2007) LEOPARD syndrome. Nobel Med 3(3): 35-38.

12. Galahitiyawa J, Wanigasinghe J, Seneviratne J, Galahitiyawa M (2015) Cutaneous markers of systemic manifestations of tuberous sclerosis complex. Int J Dermatol 54(1): e52-e55.

13. Cerbone M, Wang J, Van der Maarel SM, D’Amico A, D’Agostino A, et al. (2012) Immunodeficiency, centromeric instability, facial anomalies (ICF) syndrome, due to ZBTB24 mutations, presenting with large cerebral cyst. Am J Med Genet Part A 158 A(8): 2043-2046.

14. Twede JV DM (2009) Café au lait macules and cafe cerebro-oculo-facioskeletal syndrome: a novel association. Pediatr Dermatol 26(1): 97-99.

15. Aj K, Dermatol P, St Z, Bg A, Pathol C, et al. (1988) Correspondence 579. Lait 9(1): 579-581. 
(C) (1) This work is licensed under Creative BY DOI: 10.19080/OAJNN.2017.03.555622
Your next submission with Juniper Publishers will reach you the below assets

- Quality Editorial service

- Swift Peer Review

- Reprints availability

- E-prints Service

- Manuscript Podcast for convenient understanding

- Global attainment for your research

- Manuscript accessibility in different formats ( Pdf, E-pub, Full Text, Audio)

- Unceasing customer service

Track the below URL for one-step submission https://juniperpublishers.com/online-submission.php 